\title{
HPV16 Entry into Epithelial Cells: Running a Gauntlet
}

\author{
Snježana Mikuličić, Johannes Strunk and Luise Florin *D
}

Citation: Mikuličić, S.; Strunk, J.; Florin, L. HPV16 Entry into Epithelial Cells: Running a Gauntlet. Viruses 2021, 13, 2460. https://doi.org/ $10.3390 / \mathrm{v} 13122460$

Academic Editors: Thomas Iftner and Frank Stubenrauch

Received: 12 November 2021

Accepted: 2 December 2021

Published: 8 December 2021

Publisher's Note: MDPI stays neutral with regard to jurisdictional claims in published maps and institutional affiliations.

Copyright: (C) 2021 by the authors. Licensee MDPI, Basel, Switzerland. This article is an open access article distributed under the terms and conditions of the Creative Commons Attribution (CC BY) license (https:/ / creativecommons.org/licenses/by/ $4.0 /)$.
Institute for Virology and Research Centre for Immunotherapy (FZI), University Medical Centre of the Johannes Gutenberg-University Mainz, Obere Zahlbacher Strasse 67, 55131 Mainz, Germany;

snmikuli@uni-mainz.de (S.M.); johannes.strunk@uni-mainz.de (J.S.)

* Correspondence: lflorin@uni-mainz.de; Tel.: +49-(0)-6131-179083

\begin{abstract}
During initial infection, human papillomaviruses (HPV) take an unusual trafficking pathway through their host cell. It begins with a long period on the cell surface, during which the capsid is primed and a virus entry platform is formed. A specific type of clathrin-independent endocytosis and subsequent retrograde trafficking to the trans-Golgi network follow this. Cellular reorganization processes, which take place during mitosis, enable further virus transport and the establishment of infection while evading intrinsic cellular immune defenses. First, the fragmentation of the Golgi allows the release of membrane-encased virions, which are partially protected from cytoplasmic restriction factors. Second, the nuclear envelope breakdown opens the gate for these virus-vesicles to the cell nucleus. Third, the dis- and re-assembly of the PML nuclear bodies leads to the formation of modified virus-associated PML subnuclear structures, enabling viral transcription and replication. While remnants of the major capsid protein L1 and the viral DNA remain in a transport vesicle, the viral capsid protein L2 plays a crucial role during virus entry, as it adopts a membrane-spanning conformation for interaction with various cellular proteins to establish a successful infection. In this review, we follow the oncogenic HPV type 16 during its long journey into the nucleus, and contrast pro- and antiviral processes.
\end{abstract}

Keywords: human papillomavirus; virus entry; HPV; HPV16; L1; L2; endocytosis; trafficking; intrinsic immunity; restriction factor

\section{Introduction}

Human papillomaviruses are causally associated with multiple human cancers, including cervical as well as head and neck cancer. They are small DNA tumor viruses that infect the epithelium of skin and mucosa. Based on their potency to induce cancer, which was initially described by Harald zur Hausen [1], HPVs are divided into low- and high-risk HPV types. Low-risk types cause benign lesions, while high-risk types, also termed as oncogenic or carcinogenic HPVs, can immortalize epithelial cells. Therefore, high-risk types are declared as causative agents for premalignant and malignant changes [2,3]. HPVs are highly prevalent in the human population, but most infections are under tight control of the immune system and therefore asymptomatic and self-resolving. On the other hand, HPV has evolved mechanisms to evade host immune defenses enabling persistent infections, virus replication, and oncogenesis [3-7].

Structurally, papillomaviruses are nonenveloped viruses of about $55 \mathrm{~nm}$ in diameter. The icosahedral capsid has been shown to have an enormous degree of flexibility and is composed of 360 copies of the major capsid protein L1 and 12-72 copies of the minor capsid protein L2 and contains the approximately $8 \mathrm{~kb}$ circular double-stranded DNA genome [8-12].

The HPV replication cycle involves three successive major steps: (1) virus entry including delivery of the viral genome to the host-cell nucleus, (2) viral gene expression and genome replication, (3) and eventually virus assembly and release. Expression of the viral genes, especially of the late genes including L1 and L2, is linked to differentiation 
processes of the epithelium. For this reason, it is difficult to propagate papillomaviruses in cell culture. To circumvent this limitation, the majority of papillomavirus research is based on the substitutes of naïve viral particles, such as virus-like particles (VLPs), pseudovirions (PsVs), and quasivirions (QVs) [13]. VLPs are composed of the viral capsid proteins L1 and L2, whereas PsVs and QVs, in addition to the capsid, contain a pseudogenome encoding a reporter gene or a modified HPV genome, respectively. Recently generated LCR-PsVs, in which the long control region (LCR) of the HPV genome regulates the reporter gene, allow quick and biologically safe particle production to track infection including the role of transcription factors during early viral gene expression [14].

In this review, we focus on the first step of the HPV16 replication cycle, including the complex extracellular and intracellular processes of HPV16 entry into epithelial cells and the viral strategies to overcome various cellular antiviral defense mechanisms (see Figure 1).

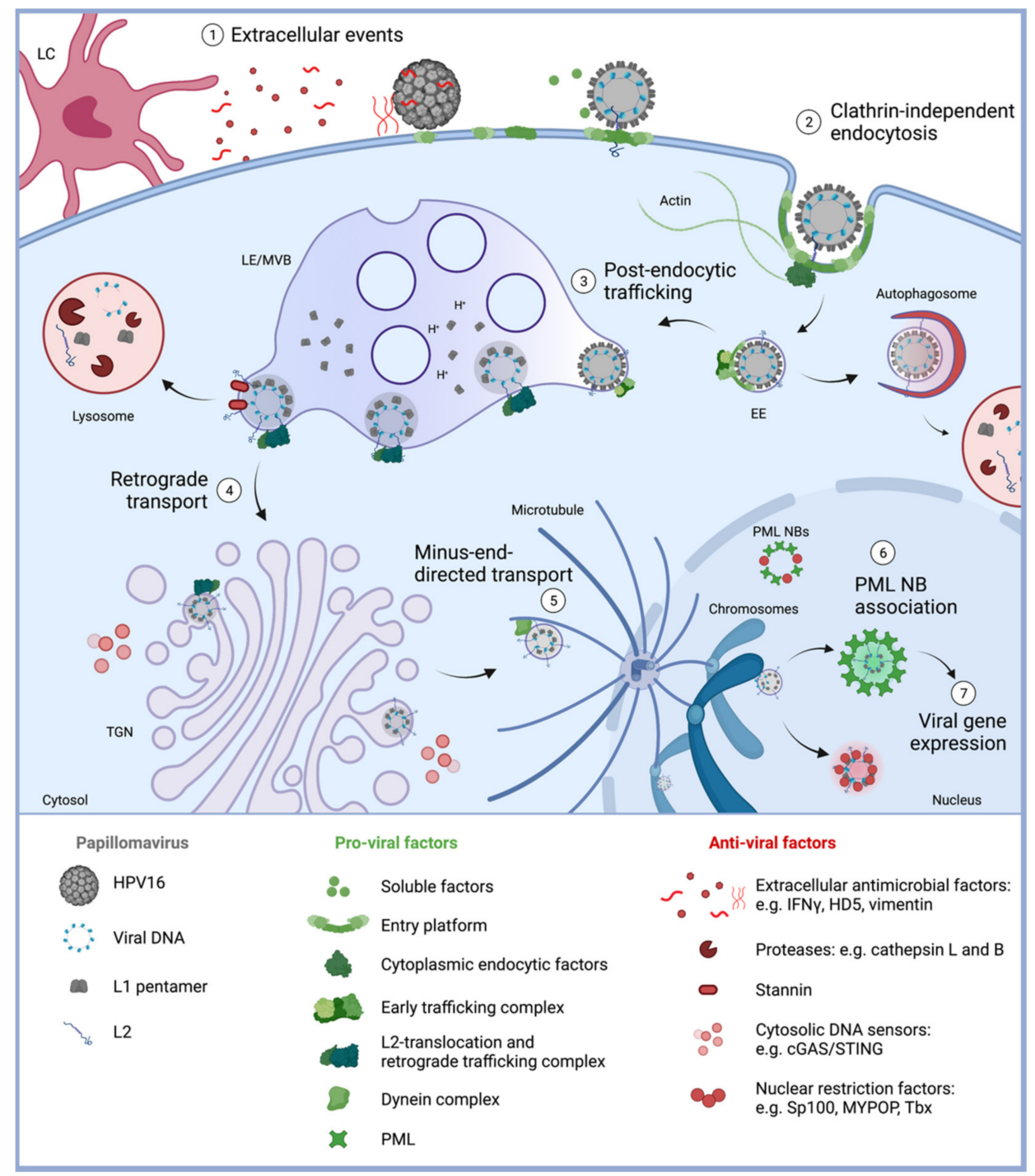

Figure 1. Diagram of HPV16 entry into their host cells with a focus on host restriction factors. (1) Extracellular events. HPV16 requires mitotically active epithelial cells for a successful infection and subsequent replication. However, various defense mechanisms form a physical, chemical or biological barrier to prevent viral access. This includes nondividing cells, extracellular antimicrobial factors, such as HD5 and vimentin, and innate immune cells including Langerhans cells (LC). Nevertheless, virions gain access through epithelial wounding, allowing the attachment to virus receptors, conformational changes of the capsid, and formation of an entry platform. (2) Clathrinindependent endocytosis. HPV enter epithelial cells via an unconventional clathrin-independent 
endocytic pathway that involves multiple signaling events, resulting in transmembrane protein clustering, recruitment of cytoplasmic endocytosis factors, and induction of actin dynamics. These events induce inward budding and fission of the membrane to noncoated vesicles. (3) Post-endocytic trafficking. Once inside the cell, trafficking adaptors form an early trafficking complex to facilitate early endosome (EE) maturation and virus trafficking to late endosome/multivesicular bodies (LE/MVB). The low $\mathrm{pH}$ inside of LE/MVBs facilitates capsid disassembly. Stable L2 insertion into the endosomal membrane is assisted by a translocation complex and allows further trafficking and virus escape from autophagosomal and lysosomal degradation by proteases. (4) Retrograde transport. L2 interaction with protein complexes involved in retrograde trafficking fulfill the subsequent virus transport to the TGN. With L2 as the only viral component being exposed to the cytosol, the infectious complex evades cytosolic DNA sensors, including the cGAS/STING pathway. The antiviral transmembrane protein stannin can induce sorting of HPV16 to lysosomes and virus degradation. (5) Minus-end directed transport. With the onset of mitosis, the fragmentation of the TGN and breakdown of the nuclear membrane allow the release and transport of membrane-encased virions towards mitotic chromatin. Here, the minus-end directed transport along microtubules is dependent on L2 interaction with the dynein motor complex and components of nuclear import machinery. Tethering of the virus vesicle to mitotic chromatin facilitates the localization inside the nucleus after completion of mitosis. (6) PML NB association. Inside the nucleus, released viral DNA can be detected and repressed by nuclear restriction factors, such as Sp100 and MYPOP. HPV16 association with reassembling PML NBs after mitosis leads to modified virus-associated PML NBs, probably providing a protective environment for the establishment of infection and (7) viral gene expression. Created with BioRender.com (accessed on: 12 November 2021).

\section{Extracellular Events}

The extracellular events comprise virus translocation across physical barriers, attachment to mitotically active cells, conformational changes of the capsid, and formation of the entry platform.

The mucous epithelium represents the first barrier. Secretion of viscous fluid containing enzymes and antimicrobial peptides (extracellular antimicrobial factors), along with layers of nondividing cells, can impede access to basal mitotically active cells of the epidermis. Wounding facilitates the access and exposes virus-attachment factors on the basement membrane or on the cell surface of basal cells to initiate infection [15]. Interactions of positively charged lysine residues of the major capsid protein L1 with negatively charged heparan sulfate proteoglycan (HSPG) cause conformational changes of both capsid proteins, which in turn may weaken the virus bond to these glycans [16-21]. Further conformational changes of the capsid are mediated by the peptidyl-prolyl cis/trans isomerase cyclophilin B (CyPB) and lead to exposure of the L2 N-terminus [22]. These initial changes in the virus structure not only enable the capsid to bind to downstream entry factors such as priming proteases but also might provide a window for antimicrobial peptides such as $\alpha$-defensins to attack (cellular defense mechanisms and proteins are summarized in Table 1).

Additional modifications in the capsid structure induced by proteolytic cleavage of HPV16 L1 and L2 by the secreted trypsin-like serine protease kallikrein-8 (KLK8) and the proprotein convertase furin, respectively, have been suggested to contribute to the slow and asynchronous internalization kinetics and to promote subsequent steps of the infectious entry pathway [23-28].

Parallel to structural changes on the capsid, HPV-induced together with virus-independent signaling events via HSPGs, integrins, and growth factor receptors (GFRs) support the HPV16 entry pathway [29-35]. Host-cell sheddases such as ADAM17, a disintegrin and metalloproteinase 17 , cleave the proform of various membrane-bound signaling molecules that bind to GFRs and activate the mitogen-activated protein kinase (MAPK) ERK1/2 signaling pathway. The efficiency of ADAM17-mediated ERK activation and the subsequent virus entry platform formation can be regulated by a member of the tetraspanin family, the Cluster of Differentiation 9 (CD9 or tetraspanin-29, Tspan-29), [36-38]. This transmem- 
brane protein provides a scaffold for ADAM17 and its epidermal GFR (EGFR)-activating substrates [39]. Downstream of proteinases, the released growth factors (GFs) activate EGFR, which is suggested to result in the translocation of the phospholipid-binding protein annexin A2/S100A10 heterotetramer (A2t) to the outer leaflet of the plasma membrane. This process probably supports A2t interaction with L2 $[40,41]$ and the recruitment of the preassembled entry receptor components, EGFR and tetraspanin CD151 (Tspan-24), to virus-binding sites [34]. Additional roles of cell-surface A2t, that may affect HPV infection, comprise the HPV-mediated suppression of the cell-mediated immune response by decreasing Langerhans cell maturation and the regulation of ADAM-mediated ectodomain shedding of GFs [42-44].

The association of GFs and cleaved HSPGs with the viral capsid may support the formation of the HPV16 entry platform. This scenario is likely, as virions are found in complexes with GFs, their receptors, and soluble HSPGs [32]. Laminin-332 and lamininbinding integrins have been shown to bind HPV16 particles and are therefore suggested as additional components of the entry receptor complex [45-50]. The tetraspanin CD151 not only associates with EGFR but also regulates integrin activities by influencing their positioning within tetraspanin-enriched microdomains [34,50-55] and is crucial for the process of HPV16 endocytosis into their host cells [56-59]. In general, diverse tetraspanins orchestrate the spatiotemporal coordination of viral entry receptor components by anchoring specific proteins to one site on the cell membrane. This results in the formation of microclusters that further organize into larger assemblies. These microdomains enable efficient cleavage of cellular and viral proteins, signaling, and membrane dynamics, leading to virus endocytosis $[60,61]$.

In contrast to proviral factors, recognition of HPV by the innate immune system can inhibit virus entry and infection. For example, human $\alpha$-defensins are a family of secreted host-defense peptides and effector components of innate immunity. Particularly, $\alpha$-defensin 5 (HD5) displays its potent activity against HPV16 infection [62]. A model proposes that interaction of HD5 with the C-terminal tail of the major capsid protein L1 stabilizes the HPV16 capsid and prevents the access of the priming protease furin to its substrate, the minor capsid protein L2. Thereby, HD5 inhibits proteolytic processing of the capsid, redirects the incoming viral particles to the lysosomes, accelerates the degradation of internalized capsid proteins and restricts infection [63-65] (see Table 1). Vimentin and the antiviral cytokine interferon gamma (IFN- $\gamma$ ) might also act as virus-restriction factors. Binding of extracellular soluble vimentin to incoming HPV16 particles leads to reduced virus internalization [66]. In general, IFN- $\gamma$, is released from stimulated immune cells to induce expression of antiviral genes. However, in HPV16 infection, IFN- $\gamma$ seems to act in a more direct manner. Treatment of cells with IFN- $\gamma$ stimulates the JAK2/STAT1 pathway, which leads to decreased L1 proteolytic cleavage and retention of L2 and the viral genome in LE/MVBs, most likely resulting in the degradation of internalized capsid [67].

Table 1. Cellular defense mechanisms and antiviral factors providing intrinsic immunity against HPV16 during the entry pathway are listed in alphabetical order.

\begin{tabular}{ccc}
\hline Cellular Defense & Impact on HPV16 Entry & References \\
\hline Alpha-defensins & $\begin{array}{c}\text { Antimicrobial peptide } \alpha \text {-defensin 5 (HD5) binds to the C-terminal tail } \\
\text { of L1 and negatively charged regions of L2. L1/L2/HD5 interaction } \\
\text { inhibits L2 cleavage by furin, stabilizes the capsid, alters virus } \\
\text { trafficking and accelerates capsid protein degradation. }\end{array}$ \\
\hline Autophagy & $\begin{array}{c}\text { HPV-mediated activation of the mTOR pathway suppresses autophagy. } \\
\text { Inhibition of autophagy delays degradation of L1 enabling efficient } \\
\text { infection. Reduction in L2 polyubiquitination by TSG101/L2 } \\
\text { interaction might contribute to bypass autophagy. }\end{array}$ \\
\hline Cathepsins & $\begin{array}{c}\text { Internalized viruses can be routed to lysosomes and degraded by } \\
\text { acid-dependent proteases cathepsin L or B. }\end{array}$ \\
\hline [33,68,69]
\end{tabular}


Table 1. Cont.

\begin{tabular}{|c|c|c|}
\hline Cellular Defense & Impact on HPV16 Entry & References \\
\hline cGAS/STING & $\begin{array}{l}\text { Localization of viral DNA to the cytosol activates the cGAS/STING } \\
\text { pathway and the activation of defense mechanisms. HPV16 DNA } \\
\text { remains in a transport vesicle that prevents the DNA sensing. }\end{array}$ & {$[71]$} \\
\hline Interferon-gamma & IFN- $\gamma$ decreases L1 proteolytic priming and retains L2 in endosomes. & [67] \\
\hline Langerhans cells (LC) & $\begin{array}{l}\text { LC are the tissue-resident macrophages of the epithelium presenting } \\
\text { virus antigens. HPV16 suppresses LC maturation and the } \\
\text { cell-mediated immune response through interaction with A2t. }\end{array}$ & [44] \\
\hline MYPOP & $\begin{array}{l}\text { MYPOP senses incoming viruses via interaction with L2 and blocks } \\
\text { viral early gene expression. L2 interaction with MYPOP enhances } \\
\text { MYPOP binding to the viral DNA (LCR). }\end{array}$ & [14] \\
\hline Sp100 & $\begin{array}{l}\text { Sp100 represses viral gene expression. HPV16 delays the recruitment of } \\
\text { this restriction factor probably to enable initial gene expression. }\end{array}$ & {$[72,73]$} \\
\hline Stannin & $\begin{array}{c}\text { Stannin interacts with L1 and impairs the L2/retromer interaction and } \\
\text { accelerates virus degradation. }\end{array}$ & [74] \\
\hline $\begin{array}{l}\text { Tbx2 } \\
\text { Tbx3 }\end{array}$ & $\begin{array}{l}\text { T-box proteins, Tbx2 and Tbx3, repress the activity of the HPV16 LCR } \\
\text { and might play a role in the regulation of HPV gene expression. }\end{array}$ & [75] \\
\hline Vimentin & $\begin{array}{l}\text { Soluble extracellular vimentin inhibits HPV16 uptake by direct binding } \\
\text { to the incoming virus. }\end{array}$ & [66] \\
\hline
\end{tabular}

\section{Clathrin-Independent Endocytosis}

HPV16 particles trigger their uptake into cells by clustering components of the entry receptor complex into large entry platforms, so-called endocytic pits. As mentioned above, multiple proteins have been suggested as such components, including tetraspanins, laminin-binding integrins, growth-factor receptors, and the annexin A2 heterotetramer. Simultaneous binding of capsid proteins with entry receptor components might induce initial platform formation and membrane curvature, both required for efficient virus endocytosis.

As demonstrated by several electron microscopical analyses, inward budding of the HPV16-associated endocytic pit results in the formation of noncoated vesicles of about $100 \mathrm{~nm}$ in diameter [31,58,76,77]. This process is independent of the classical key factors clathrin, caveolin, and dynamin $[31,57,58]$. Therefore, it is believed that HPV16 initiates or follows a novel endocytic pathway that requires tetraspanins [58] and the actin cytoskeleton [31,57,78], and shares characteristics of macropinocytosis [31].

Like entry platform formation, HPV16 endocytosis is promoted by host-cell signaling via EGFR [31,32,34,36,50,76]. Downstream of EGFR, Abelson tyrosine-protein kinase (Abl) regulates actin remodeling to inhibit macropinocytosis of EGFR, favoring endocytosis into small endocytic vesicles [79]. As such, Abelson tyrosine-protein kinase 2 facilitates HPV endocytosis [76] and supports the notion that HPV16 is cointernalized with EGFR in an actin-dependent manner.

Additionally, filamentous actin, the cytoskeletal adaptor protein Obscurin-Like 1 (OBSL1), the trafficking protein particle complex subunit 8 (TRAPPC8), the Wiskott-Aldrich syndrome protein and suppressor of cAMP receptor homologue (WASH), and the BAR domain-containing sorting nexin 2 (SNX2), have been shown to localize at the HPV16 endocytic pits [80-83]. As demonstrated for CD151, the cytoplasmic endocytic factors WASH and SNX2 are cointernalized with virus particles and may trigger actin dynamics, membrane curvature, virus internalization and vesicle scission [56,82]. This may function by complex formation with CD151 and/or OBSL1, as basolateral membrane-bound virus particles were found to be surrounded by tetraspanins, OBSL1, and actin. These findings support the idea that OBSL1 is a linker between virus-induced endocytic pits and the actin cytoskeleton $[80,81]$. On the other hand, the interaction of OBSL1 with L2 points towards a later function, because L2 penetrates into the cytosol most likely just before trafficking from the late endosome towards the nucleus. Alternatively, initial L2 membrane insertion 
might occur already on the plasma membrane, enabling L2 interaction with cytoplasmic factors required for HPV16 endocytosis and subsequent trafficking.

\section{Post-Endocytic Trafficking to the Disassembly Compartment}

After endocytosis, the HPV16 entry platform further determines the post-endocytic trafficking of the virus. For example, tetraspanins and A2t both colocalize with HPV on the cell surface and are cointernalized with the virus during endocytosis $[56,58,84]$. This internalization process results in the recruitment of trafficking adaptors, such as syntenin-1 and Rab5, to virus-filled endosomes [77]. Interaction of syntenin-1 with the C-terminus of CD63 (Tspan-30) promotes maturation and trafficking of the virus-filled early endosomes to late endosomes/multivesicular bodies (LE/MVB) [77]. ESCRT components such as the vacuolar protein sorting-associated protein 4 (VPS4), the tumor susceptibility 101 (Tsg101) and the ALG-2-interacting protein X (Alix) together with sorting nexin 17 (SNX17) and the cytosolic-containing TCP1 (CCT) chaperonin complex, are additional trafficking proteins that can be recruited to incoming HPV and have been proposed to play a role during this intracellular trafficking/maturation process [69,77,85-88]. Many of them have the ability to interact with L2 (see Table 2). Moreover, the sorting adaptor syntenin-1 can bind to Rab-GTPases, Rab5 and Rab7, principal regulators of endocytic trafficking [89] suggested to control endocytic routes of internalized HPV (reviewed in [90]).

Similar to tetraspanins, Rab-GTPases, and the ESCRT machinery, A2t promotes membrane dynamics and vesicular trafficking [91]. Therefore, A2t might cooperate with other trafficking factors in HPV16 entry. It was shown to associate with incoming viruses and CD63 and to promote virus trafficking to LE/MVBs $[40,84]$. The continuously decreasing $\mathrm{pH}$ inside maturing endosomes facilitates capsid disassembly, partial dissociation of L1 from the infectious complex, as well as L2 translocation across the endosomal membrane [92-95].

Alternatively, HPV can be eliminated by degradation. Autophagy-mediated clearance of intracellular pathogens (also called xenophagy) is one of the fundamental degradation pathways of the cell that contributes to antimicrobial defense [96]. The recruitment of the microtubule-associated protein 1 light chain 3 (LC3) and autophagy-related (ATG) proteins to autophagosomal membranes and polyubiquitinated targets leads to inclusion of pathogens in double-membrane vesicles called autophagosomes. Like many pathogens, HPV16 has been detected in autophagosomes [97]. On the one hand, HPV16 induces the formation of LC3 puncta and LC3 association with ATG9, suggesting induction of autophagy $[68,98]$. On the other hand, HPV16 has evolved ways to evade this degradation compartment. HPV-mediated activation of the phosphatidylinositol 3-kinase (PI3K) and mammalian target of rapamycin (mTOR) pathway downstream of EGFR efficiently suppresses autophagy and enables infection [33]. The TSG101-mediated reduction in L2 polyubiquitination might additionally contribute to bypassing autophagy [69].

Antiviral factors which prevent capsid priming, disassembly or L2 translocation, enhance the degradation of the capsid proteins (see Table 1) via the lysosomal pathway or autophagy. The latter also leads to proteolytic degradation of the autophagosomal content, as autophagosomes fuse with lysosomes during maturation to autophagolysosomes. Aciddependent proteases such as cathepsins have been assumed to contribute to the antiviral degradation process [70].

\section{L2 Translocation and Retrograde Transport}

Numerous studies uncovered cellular interaction partners of the HPV16 minor capsid protein L2 (summarized in Table 2). In most cases, these L2 partners assist in L2 translocation across the host-cell membrane and subsequent retrograde transport (reviewed in [99]). As described above, the process might start early in infection, with initial conformational changes of the capsid structure allowing L2 exposure, priming and accessibility of L2 to cellular proteins. Cyclophilin B contributes not only to initial conformational changes in the capsid, but also assists in dissociation of L1 and L2 in LE/MVBs [94]. The membrane- 
destabilizing peptide near the $\mathrm{C}$ terminus of $\mathrm{L} 2$, which contains a cell-penetrating peptide (CPP), might initiate membrane penetration $[100,101]$ which eventually leads to incorporation of the L2 transmembrane domain into the vesicular lipid bilayer, a luminal N-terminus and the majority of the protein being exposed to the cytosol [95,102].

The relevance of the transmembrane protease $\gamma$-secretase for the HPV entry process is well-documented [99,103-108]. Here, a novel chaperone-like function of the $\gamma$-secretase seems to be more important than its role as a protease, as it enables low $\mathrm{pH}$-dependent membrane insertion of the furin-cleaved L2 that is required for further trafficking [25,104-106]. Additional chaperones from the Hsc/Hsp70 family can form physical complexes not only with $\gamma$-secretase but also with L2, and might therefore assist in the process of membrane insertion $[104,109]$. Moreover, $\gamma$-secretase is located in and regulated by tetraspanin microdomains [110]. Therefore, it is conceivable that tetraspanins provide a scaffold not only for the endocytic machinery but also for the L2-translocation complex. Consistent with this model, the cytosolic $\gamma$-secretase adaptor p120 catenin forms a complex with HPV, probably mediated via a transmembrane protein at early time points during viral internalization as well as trafficking, and promotes interaction of L2 with $\gamma$-secretase to support membrane insertion [103]. Despite many convincing studies, the exact mechanism and the role of the involved factors that mediate L2 translocation are not yet fully understood.

Recent findings suggested that the viral genome and remnants of the capsid remain in a transport vesicle during the complete intracellular transport, to evade innate immune detection by cellular restriction factors [71,111-113]. Only L2 extends the vesicle to hijack the cellular transport machinery [95]. Interactions of L2 with components of the retromer complex and probably a newly identified retriever complex fulfill endosome tubulation, vesicle formation, and the retrograde transport of HPV16 from the endosome to the trans-Golgi network (TGN) $[92,114,115]$. Rab-GTPases and numerous molecules including SNX proteins, the TBC1 domain family member 5 (TBC1D5), and the endoplasmic reticulum (ER)-anchored protein vesicle-associated membrane protein (VAMP)-associated protein (VAP), may assist in these processes [90,99,115-118]. For example, TBC1D5 is recruited to $\mathrm{L} 2$ /retromer at the endosomal membrane, which subsequently stimulates hydrolysis of Rab7-GTP to drive retromer disassembly from the HPV [117]. After retromer dissociation, virus-containing vesicles traffic to the TGN, where the cargo is delivered by membrane fusion.

Results of one study has indicated that during the intracellular HPV16 trafficking process, the small transmembrane protein stannin is able to sense incoming viruses via interaction with L1. This interaction impairs binding of L2 to the retromer, likely by preventing L2 translocation across vesicular membranes, which again leads to routing the virus for lysosomal degradation and restriction of HPV infection [74].

\section{Minus-End-Directed Transport to PML Nuclear Bodies}

The onset of mitosis is accompanied by three cellular reorganization processes required for HPV16 transport into the host-cell nucleus and the establishment of infection [119]. The reliance of HPV16 on these processes explains the papillomavirus dependency on a cell division cycle for a successful infection.

First, the fragmentation of the TGN during mitosis promotes the release of membraneencased virions, enabling subsequent trafficking of the virus and evasion of cellular immune defenses $[71,111,120]$. In contrast to viruses which release their genome into the cytoplasm, HPV16 resides in the Golgi-derived vesicle until mitosis is completed [111]. This enables the virus to escape from cytosolic DNA sensors such as the cyclic GMPAMP synthase-stimulator of interferon genes (cGAS/STING) pathway and downstream defense mechanisms [71]. The nonreceptor tyrosine kinase Pyk2 as well as interaction of L2 with TRAPPC8 have been suggested to assist in Golgi exit and destabilization, respectively $[83,121]$. OBSL1, which can bind to L2's cytoplasmic part, may contribute to this process, as OBSL1 has been found to be a critical regulator of Golgi morphogene- 
sis $[80,122]$. Further work is needed to understand how HPV16 exits the Golgi or whether HPV contributes to its fragmentation.

After dissociation from the TGN, the virus-vesicle associates with microtubules via L2 interaction with the dynein motor complex [111,123,124]. This most likely facilitates the transport along astral microtubules located between the TGN and the microtubuleorganizing center (MTOC). L2 interaction with dynein light chains Tctex-Type 1 and 3 (DYNLT1/Tctex1 and DYNLT3) is mediated via a consensus Tctex-interaction domain located in the C-terminus of L2 [123,124].

The second mitosis-associated reorganization process required for HPV infection is the nuclear envelope breakdown $[125,126]$. It enables a direct transport to the cellular DNA and opens the gate for the virus-vesicles to the cell nucleus. Here, L2 forms a physical complex not only with the dynein light chains but also with the Ran-binding protein 10 (RanBP10) and karyopherin alpha 2 (KPNA2) to promote the minus-end-directed transport of the virus towards mitotic chromatin [127]. Conserved nuclear import signals (NLS) within L2 and interactions of L2 with components of the nuclear import machinery (including KPNA2) have been shown to play a role for L2 nuclear import [128-130] and seem to be also required during virus entry, although the nuclear envelope is absent during mitosis. The observation that L2/Hsc70 interaction promotes the release of newly synthesized L2 from dynein complexes suggests a role of the Hsc70 chaperone for the release of incoming virus from the transport complex [123].

In contrast to earlier assumptions, parts of the L1-formed capsid appear to remain associated with L2 and the viral DNA during nuclear entry [112,113]. As L1 and the viral DNA are still hidden in the vesicle, L2 tethering to mitotic chromatin promotes the inclusion of HPV16 into the newly formed nucleus $[111,120,126]$. For binding to mitotic chromosomes, the virus requires a central chromosome-binding region (CBR) of the L2 protein and likely an unknown prometaphase activated factor [126]. The CBR contains a highly conserved SUMO-interacting motif (SIM) [131] that is indispensable for chromosome tethering and incorporation of the viral genome into newly formed promyelocytic leukemia (PML) nuclear bodies (PML NBs) after mitosis [73,131]. Therefore, L2 interaction with a tethering factor that is SUMO-modified during prometaphase is likely. L2 itself can also be covalently modified at its SUMO conjugation motif (SCM), and has the ability to reorganize PML NBs [130-133]. The post-translational modification is facilitated by L2 interaction with SUMO, and may exert additional functions during a so-far-undefined step in the HPV replication cycle [131,132].

Dis- and reassembly of the PML NBs is the third mitotic reorganization process required for HPV16 infection. It leads to the formation of modified virus-associated PML NBs and enables viral transcription and replication [73,134,135]. After the release of the genome in the host-cell nucleus, repressive transcription factors (restriction factors) have access to the viral DNA, or more specifically, to the HPV long control region on the HPV16 genome. The Speckled protein 100 (Sp100), transcription factors of the T-box family, Tbx2 and Tbx3, as well as the Myb-related transcription factor, partner of profilin (MYPOP) efficiently repress viral gene expression [14,72,75]. In the case of Sp100, it has been demonstrated that HPV16 delays the recruitment of this restriction factor to the viral genome and PML protein, probably to enable initial gene expression [73]. The newly identified host restriction factor MYPOP not only binds to the viral DNA but may also sense incoming viruses via interaction with L2 [14]. MYPOP interacts directly with the C-terminal part of L2 and has been observed to colocalize with L2 and the viral DNA in the nucleus after virus entry. Moreover, L2 enhances MYPOP's binding to the viral DNA [14]. The inclusion of incoming HPV into PML NBs might play a role in protecting the viral genome from MYPOP. On the other hand, a high expression level of nuclear MYPOP in normal epithelial cells of skin and mucosa might contribute to the strong immune control of oncogenic HPV types. 


\section{Concluding Remarks}

The discovery of the unconventional clathrin-independent endocytosis pathway as well as the intracellular transport of HPV16 inside a vesicle into the cell nucleus shows that viral particles are still a unique tool to uncover new endocytosis or transport routes that are most likely not only hijacked by one virus type. The formation of tetraspanin-enriched entry platforms, for example, has also been described for coronaviruses, influenza A virus or hepatitis C virus $[60,136]$. A protected virus transport in a Golgi-derived vesicle into the cell nucleus could also represent a more common mechanism for invading viruses to evade cytoplasmic sensors for foreign nucleic acids. Studies on viral proteins have long contributed to the discovery and characterization of cellular proteins and pathways. The most famous example of HPV is certainly the discovery of p53 by investigating the HPV E6 protein $[137,138]$. Interaction screens for L2 not only contributed significantly to the elucidation of the HPV16 entry pathway but also led to the identification of the previously unknown viral restriction factor MYPOP. Future studies must show whether this transcription factor has more general functions in cellular defense, virus latency or even in preventing oncogenesis.

Table 2. Interaction partners of the HPV16 minor capsid protein L2 are listed in alphabetical order.

\begin{tabular}{|c|c|c|}
\hline L2 Partner & Impact on HPV16 Entry & References \\
\hline $\mathrm{A} 2 \mathrm{t}$ & $\begin{array}{c}\text { L2 interaction with S100A10 subunit of A2t promotes cellular uptake, } \\
\text { trafficking to late endosomal multivesicular bodies (LE/MVBs) and protects } \\
\text { the virus from lysosomal degradation. }\end{array}$ & {$[40,41,84]$} \\
\hline Beta-actin & L2/actin interaction facilitates virus infection. & [139] \\
\hline CCT complex & $\begin{array}{l}\text { L2 interaction with the CCT3 subunit of the CCT chaperonin complex } \\
\text { facilitates capsid disassembly. }\end{array}$ & [87] \\
\hline Cep68 & $\begin{array}{c}\text { Interaction of the centrosomal protein } 68 \text { (Cep68) with L2 might facilitate } \\
\text { virus infection. }\end{array}$ & [80] \\
\hline Chromatin & $\begin{array}{l}\text { L2 tethering to mitotic chromatin promotes nuclear entry. This interaction } \\
\text { requires the L2 SUMO interaction motif within the central } \\
\text { chromosome-binding region. }\end{array}$ & {$[73,126]$} \\
\hline Cyclophilin B & $\begin{array}{l}\text { Cyclophilin B contributes to initial conformational changes of L2 and } \\
\text { dissociation of L1 and L2. }\end{array}$ & {$[22,94]$} \\
\hline $\begin{array}{l}\text { Dynein } \\
\text { RanBP10 }\end{array}$ & $\begin{array}{l}\text { L2 interaction with subunits of the dynein motor complex, DYNLT1 and } \\
\text { DYNLT3, in addition to L2 interaction with the DYNLT3/RanBP10/KPNA2 } \\
\text { complex mediates minus-end-directed transport of the viral genome along } \\
\text { microtubules towards and into the nucleus. }\end{array}$ & {$[123,124,127]$} \\
\hline ESCRT & $\begin{array}{l}\text { L2 interacts with ESCRT components Tsg101 and VPS4. ESCRT can form a } \\
\text { complex with L1/L2 and is involved in endosome maturation to MVBs. } \\
\text { TSG101 reduces the levels of L2 polyubiquitination. }\end{array}$ & {$[69,85]$} \\
\hline Furin & $\begin{array}{c}\text { Furin cleavage of L2 contributes to the priming of HPV. This can occur during } \\
\text { virion morphogenesis, on the basement membrane or on the cell surface, } \\
\text { contributing to the asynchronous uptake, interaction with } \gamma \text {-secretase, and } \\
\text { subsequent trafficking. }\end{array}$ & {$[24-26,28,104,140]$} \\
\hline Gamma-secretase & $\begin{array}{c}\text { L2 binds to } \gamma \text {-secretase. A novel chaperone-like function of the } \gamma \text {-secretase } \\
\text { enables membrane insertion of L2. }\end{array}$ & [104] \\
\hline Hsc70 & $\begin{array}{l}\mathrm{L} 2 / \mathrm{Hsc} 70 \text { chaperone interaction facilitates nuclear import. Hsc70 promotes the } \\
\text { release of the vDNA/L2 from microtubules. Hsc/Hsp70 chaperones also } \\
\text { interact with the L2/ } \gamma \text {-secretase complex. }\end{array}$ & {$[104,109,123]$} \\
\hline Membranes & $\begin{array}{l}\text { L2's membrane-destabilizing peptide or cell-penetrating peptide (CPP) near } \\
\text { the C-terminus initiates membrane penetration until the transmembrane } \\
\text { domain near the N-terminus of L2. }\end{array}$ & [100-102] \\
\hline
\end{tabular}


Table 2. Cont.

\begin{tabular}{|c|c|c|}
\hline L2 Partner & Impact on HPV16 Entry & References \\
\hline MYPOP & $\begin{array}{l}\text { MYPOP senses incoming viruses via interaction with L2 and blocks viral early } \\
\text { gene expression. L2/MYPOP interaction enhances MYPOP's binding to the } \\
\text { viral DNA (LCR). }\end{array}$ & [14] \\
\hline $\begin{array}{l}\text { Nuclear } \\
\text { import receptor }\end{array}$ & $\begin{array}{c}\text { L2 interacts with nuclear import receptors such as karyopherin alpha 2, } \\
\text { enabling nuclear import not only during HPV16 morphogenesis but also } \\
\text { during entry. }\end{array}$ & {$[127,128]$} \\
\hline OBSL1 & $\begin{array}{l}\text { OBSL1 enables HPV endocytosis probably by linking the virus entry platform } \\
\text { to the actin cytoskeleton. Further trafficking steps might be facilitated by } \\
\text { L2/OBSL1 interaction. }\end{array}$ & [80] \\
\hline p120-catenin & $\begin{array}{l}\text { p120-catenin promotes L2/ } \gamma \text {-secretase complex formation and L2 } \\
\text { membrane insertion. }\end{array}$ & [103] \\
\hline PML & $\begin{array}{l}\text { L2's SUMO interaction motif (L2 IVAL, aa 286-9) enables incorporation into } \\
\text { newly formed PML NBs after mitosis. }\end{array}$ & {$[73,131]$} \\
\hline Retromer & $\begin{array}{l}\text { L2 interaction with retromer subunits VPS35 promotes endosome to Golgi } \\
\text { trafficking and stabilizes membrane insertion of L2. L2/VPS35 enhances } \\
\text { complex formation between retromer, Rab7, and TBC1D5, supporting } \\
\text { disassembly of the retromer-HPV complex. L2 recruits retromer and retriever } \\
\text { complexes via the same L2 domain. }\end{array}$ & {$[92,114,115,117,141]$} \\
\hline $\begin{array}{l}\text { Sorting Nexin } 17 \\
\text { Sorting Nexin } 27\end{array}$ & $\begin{array}{c}\text { L2/SNX17 interaction promotes trafficking to LE/MVBs, capsid disassembly, } \\
\text { and protects L2 from lysosomal degradation. This interaction may support } \\
\text { retromer recruitment. L2/SNX27 interaction facilitates trafficking probably by } \\
\text { supporting retriever interaction. }\end{array}$ & {$[86,88,115,142]$} \\
\hline SUMO & $\begin{array}{l}\text { L2/SUMO covalent conjugation via the L2 SCM increases L2 stability and } \\
\text { inhibits L1 binding. L2/SUMO interaction via the highly conserved SIM (L2 } \\
\text { IVAL, aa 286-9) enhances L2 SUMOylation and PML NB association. }\end{array}$ & {$[131,132]$} \\
\hline $\begin{array}{l}\text { PATZ, } \\
\text { PLINP, } \\
\text { PMSP, } \\
\text { TIN-Ag-RP }\end{array}$ & $\begin{array}{l}\text { Functions of the interaction between HPV16 L2 protein and POZ-AT-Zn-finger } \\
\text { protein (PATZ), papillomavirus L2 interacting nuclear protein (PLINP), } \\
\text { papillomavirus minor structural protein interacting protein (PMSP), and } \\
\text { tubular-nephritis antigen-related protein (TIN-Ag-RP) are unknown. }\end{array}$ & [143] \\
\hline $\begin{array}{l}\text { Tbx2 } \\
\operatorname{Tbx3}\end{array}$ & $\begin{array}{l}\text { L2/Tbx interaction enhances repressive activity of T-box proteins Tbx2 and } \\
\text { Tbx3 on the LCR as well as Tbx silencing of E6 expression. }\end{array}$ & [75] \\
\hline TRAPPC8 & L2/TRAPPC8 interaction may contribute to Golgi destabilization. & [83] \\
\hline
\end{tabular}

Author Contributions: S.M., J.S. and L.F. all contributed to the writing of this review. All authors have read and agreed to the published version of the manuscript.

Funding: Johannes Strunk and Luise Florin are supported by grants from the Max Planck Graduate Center with the Johannes Gutenberg Universität Mainz (MPGC) and the German Research Foundation (Deutsche Forschungsgemeinschaft, DFG FL 696/3-2), respectively.

Institutional Review Board Statement: Not applicable.

Informed Consent Statement: Not applicable.

Data Availability Statement: Not applicable.

Acknowledgments: We acknowledge the vast amount of work that has led to our current understanding of HPV16 entry. We are grateful to Bob Persiko for his critical reading of the manuscript.

Conflicts of Interest: The authors declare no conflict of interest.

\section{References}

1. zur Hausen, H. Papillomaviruses in the Causation of Human Cancers-a Brief Historical Account. Virology 2009, 384, $260-265$. [CrossRef]

2. de Villiers, E.-M. Cross-Roads in the Classification of Papillomaviruses. Virology 2013, 445, 2-10. [CrossRef] [PubMed] 
3. McBride, A.A. Human Papillomaviruses: Diversity, Infection and Host Interactions. Nat. Rev. Microbiol. 2021. [CrossRef]

4. Porter, S.S.; Stepp, W.H.; Stamos, J.D.; McBride, A.A. Host Cell Restriction Factors That Limit Transcription and Replication of Human Papillomavirus. Virus Res. 2017, 231, 10-20. [CrossRef]

5. Zhou, C.; Tuong, Z.K.; Frazer, I.H. Papillomavirus Immune Evasion Strategies Target the Infected Cell and the Local Immune System. Front. Oncol. 2019, 9, 682. [CrossRef] [PubMed]

6. Roden, R.B.S.; Stern, P.L. Opportunities and Challenges for Human Papillomavirus Vaccination in Cancer. Nat. Rev. Cancer 2018, 18, 240-254. [CrossRef] [PubMed]

7. Gusho, E.; Laimins, L. Human Papillomaviruses Target the DNA Damage Repair and Innate Immune Response Pathways to Allow for Persistent Infection. Viruses 2021, 13, 1390. [CrossRef]

8. Buck, C.B.; Day, P.M.; Trus, B.L. The Papillomavirus Major Capsid Protein L1. Virology 2013, 445, 169-174. [CrossRef] [PubMed]

9. Modis, Y.; Trus, B.L.; Harrison, S.C. Atomic Model of the Papillomavirus Capsid. EMBO J. 2002, 21, 4754-4762. [CrossRef]

10. Chen, X.S.; Garcea, R.L.; Goldberg, I.; Casini, G.; Harrison, S.C. Structure of Small Virus-like Particles Assembled from the L1 Protein of Human Papillomavirus 16. Mol. Cell. 2000, 5, 557-567. [CrossRef]

11. Buck, C.B.; Cheng, N.; Thompson, C.D.; Lowy, D.R.; Steven, A.C.; Schiller, J.T.; Trus, B.L. Arrangement of L2 within the Papillomavirus Capsid. J. Virol. 2008, 82, 5190-5197. [CrossRef]

12. Goetschius, D.J.; Hartmann, S.R.; Subramanian, S.; Bator, C.M.; Christensen, N.D.; Hafenstein, S.L. High Resolution Cryo EM Analysis of HPV16 Identifies Minor Structural Protein L2 and Describes Capsid Flexibility. Sci. Rep. 2021, 11, 3498. [CrossRef]

13. Biryukov, J.; Meyers, C. Papillomavirus Infectious Pathways: A Comparison of Systems. Viruses 2015, 7, 4303-4325. [CrossRef]

14. Wüstenhagen, E.; Boukhallouk, F.; Negwer, I.; Rajalingam, K.; Stubenrauch, F.; Florin, L. The Myb-Related Protein MYPOP Is a Novel Intrinsic Host Restriction Factor of Oncogenic Human Papillomaviruses. Oncogene 2018, 75, 159. [CrossRef] [PubMed]

15. Roberts, J.N.; Buck, C.B.; Thompson, C.D.; Kines, R.; Bernardo, M.; Choyke, P.L.; Lowy, D.R.; Schiller, J.T. Genital Transmission of HPV in a Mouse Model Is Potentiated by Nonoxynol-9 and Inhibited by Carrageenan. Nat. Med. 2007, 13, 857-861. [CrossRef]

16. Knappe, M.; Bodevin, S.; Selinka, H.-C.; Spillmann, D.; Streeck, R.E.; Chen, X.S.; Lindahl, U.; Sapp, M. Surface-Exposed Amino Acid Residues of HPV16 L1 Protein Mediating Interaction with Cell Surface Heparan Sulfate. J. Biol. Chem. 2007, 282, 27913-27922. [CrossRef] [PubMed]

17. Dasgupta, J.; Bienkowska-Haba, M.; Ortega, M.E.; Patel, H.D.; Bodevin, S.; Spillmann, D.; Bishop, B.; Sapp, M.; Chen, X.S. Structural Basis of Oligosaccharide Receptor Recognition by Human Papillomavirus. J. Biol. Chem. 2011, 286, $2617-2624$. [CrossRef] [PubMed]

18. Richards, K.F.; Bienkowska-Haba, M.; Dasgupta, J.; Chen, X.S.; Sapp, M. Multiple Heparan Sulfate Binding Site Engagements Are Required for the Infectious Entry of Human Papillomavirus Type 16. J. Virol. 2013, 87, 11426-11437. [CrossRef] [PubMed]

19. Cerqueira, C.; Liu, Y.; Kühling, L.; Chai, W.; Hafezi, W.; van Kuppevelt, T.H.; Kühn, J.E.; Feizi, T.; Schelhaas, M. Heparin Increases the Infectivity of Human Papillomavirus Type 16 Independent of Cell Surface Proteoglycans and Induces L1 Epitope Exposure. Cell. Microbiol. 2013, 15, 1818-1836. [CrossRef] [PubMed]

20. Selinka, H.-C.; Florin, L.; Patel, H.D.; Freitag, K.; Schmidtke, M.; Makarov, V.A.; Sapp, M. Inhibition of Transfer to Secondary Receptors by Heparan Sulfate-Binding Drug or Antibody Induces Noninfectious Uptake of Human Papillomavirus. J. Virol. 2007, 81, 10970-10980. [CrossRef] [PubMed]

21. Guan, J.; Bywaters, S.M.; Brendle, S.A.; Ashley, R.E.; Makhov, A.M.; Conway, J.F.; Christensen, N.D.; Hafenstein, S. Cryoelectron Microscopy Maps of Human Papillomavirus 16 Reveal L2 Densities and Heparin Binding Site. Structure 2017, 25, 253-263. [CrossRef]

22. Bienkowska-Haba, M.; Patel, H.D.; Sapp, M. Target Cell Cyclophilins Facilitate Human Papillomavirus Type 16 Infection. PLoS Pathog. 2009, 5, e1000524. [CrossRef]

23. Cerqueira, C.; Ventayol, P.S.; Vogeley, C.; Schelhaas, M. Kallikrein-8 Proteolytically Processes Human Papillomaviruses in the Extracellular Space To Facilitate Entry into Host Cells. J. Virol. 2015, 89, 7038-7052. [CrossRef] [PubMed]

24. Becker, M.; Greune, L.; Schmidt, M.A.; Schelhaas, M. Extracellular Conformational Changes in the Capsid of Human Papillomaviruses Contribute to Asynchronous Uptake into Host Cells. J. Virol. 2018, 82, e02106-17. [CrossRef]

25. Richards, R.M.; Lowy, D.R.; Schiller, J.T.; Day, P.M. Cleavage of the Papillomavirus Minor Capsid Protein, L2, at a Furin Consensus Site Is Necessary for Infection. Proc. Natl. Acad. Sci. USA 2006, 103, 1522-1527. [CrossRef]

26. Bronnimann, M.P.; Calton, C.M.; Chiquette, S.F.; Li, S.; Lu, M.; Chapman, J.A.; Bratton, K.N.; Schlegel, A.M.; Campos, S.K. Furin Cleavage of L2 During Papillomavirus Infection: Minimal Dependence on Cyclophilins. J. Virol. 2016, 90, 6224-6234. [CrossRef]

27. Day, P.M.; Lowy, D.R.; Schiller, J.T. Heparan Sulfate-Independent Cell Binding and Infection with Furin-Precleaved Papillomavirus Capsids. J. Virol. 2008, 82, 12565-12568. [CrossRef] [PubMed]

28. Kines, R.C.; Thompson, C.D.; Lowy, D.R.; Schiller, J.T.; Day, P.M. The Initial Steps Leading to Papillomavirus Infection Occur on the Basement Membrane Prior to Cell Surface Binding. Proc. Natl. Acad. Sci. USA 2009, 106, 20458-20463. [CrossRef] [PubMed]

29. Fothergill, T.; McMillan, N.A.J. Papillomavirus Virus-like Particles Activate the PI3-Kinase Pathway via Alpha-6 Beta-4 Integrin upon Binding. Virology 2006, 352, 319-328. [CrossRef] [PubMed]

30. Payne, E.; Bowles, M.; Don, A.; Hancock, J.; McMillan, N. Human Papillomavirus Type 6b Virus-like Particles Are Able to Activate the Ras-MAP Kinase Pathway and Induce Cell Proliferation. J. Virol. 2001, 75, 4150. [CrossRef] [PubMed] 
31. Schelhaas, M.; Shah, B.; Holzer, M.; Blattmann, P.; Kühling, L.; Day, P.M.; Schiller, J.T.; Helenius, A. Entry of Human Papillomavirus Type 16 by Actin-Dependent, Clathrin- and Lipid Raft-Independent Endocytosis. PLoS Pathog. 2012, 8, e1002657. [CrossRef] [PubMed]

32. Surviladze, Z.; Dziduszko, A.; Ozbun, M.A. Essential Roles for Soluble Virion-Associated Heparan Sulfonated Proteoglycans and Growth Factors in Human Papillomavirus Infections. PLoS Pathog. 2012, 8, e1002519. [CrossRef]

33. Surviladze, Z.; Sterk, R.T.; Deharo, S.A.; Ozbun, M.A. Cellular Entry of Human Papillomavirus Type 16 Involves Activation of the Phosphatidylinositol 3-Kinase/Akt/MTOR Pathway and Inhibition of Autophagy. J. Virol. 2013, 87, 2508-2517. [CrossRef] [PubMed]

34. Mikuličić, S.; Finke, J.; Boukhallouk, F.; Wüstenhagen, E.; Sons, D.; Homsi, Y.; Reiss, K.; Lang, T.; Florin, L. ADAM17-Dependent Signaling Is Required for Oncogenic Human Papillomavirus Entry Platform Assembly. eLife 2019, 8, e44345. [CrossRef] [PubMed]

35. Abban, C.Y.; Meneses, P.I. Usage of Heparan Sulfate, Integrins, and FAK in HPV16 Infection. Virology 2010, 403, 1-16. [CrossRef] [PubMed]

36. Mikuličić, S.; Fritzen, A.; Scheffer, K.; Strunk, J.; Cabañas, C.; Sperrhacke, M.; Reiss, K.; Florin, L. Tetraspanin CD9 Affects HPV16 Infection by Modulating ADAM17 Activity and the ERK Signalling Pathway. Med. Microbiol. Immunol. 2020, 7, 3863. [CrossRef]

37. Gutiérrez-López, M.D.; Gilsanz, A.; Yañez-Mó, M.; Ovalle, S.; Lafuente, E.M.; Domínguez, C.; Monk, P.N.; González-Alvaro, I.; Sánchez-Madrid, F.; Cabañas, C. The Sheddase Activity of ADAM17/TACE Is Regulated by the Tetraspanin CD9. Cell. Mol. Life Sci. 2011, 68, 3275-3292. [CrossRef] [PubMed]

38. Liu, J.; Zhu, G.; Jia, N.; Wang, W.; Wang, Y.; Yin, M.; Jiang, X.; Huang, Y.; Zhang, J. CD9 Regulates Keratinocyte Migration by Negatively Modulating the Sheddase Activity of ADAM17. Int. J. Bio. Sci. 2019, 15, 493-506. [CrossRef] [PubMed]

39. Reyes, R.; Cardeñes, B.; Machado-Pineda, Y.; Cabañas, C. Tetraspanin CD9: A Key Regulator of Cell Adhesion in the Immune System. Front. Immunol. 2018, 9, 863. [CrossRef]

40. Dziduszko, A.; Ozbun, M.A. Annexin A2 and S100A10 Regulate Human Papillomavirus Type 16 Entry and Intracellular Trafficking in Human Keratinocytes. J. Virol. 2013, 87, 7502-7515. [CrossRef]

41. Woodham, A.W.; Silva, D.M.D.; Skeate, J.G.; Raff, A.B.; Ambroso, M.R.; Brand, H.E.; Isas, J.M.; Langen, R.; Kast, W.M. The S100A10 Subunit of the Annexin A2 Heterotetramer Facilitates L2-Mediated Human Papillomavirus Infection. PLoS ONE 2012, 7, e43519. [CrossRef]

42. Nakayama, H.; Fukuda, S.; Inoue, H.; Nishida-Fukuda, H.; Shirakata, Y.; Hashimoto, K.; Higashiyama, S. Cell Surface Annexins Regulate ADAM-Mediated Ectodomain Shedding of Proamphiregulin. Mol. Biol. Cell 2012, 23, 1964-1975. [CrossRef] [PubMed]

43. Ozbun, M.A.; Campos, S.K. The Long and Winding Road: Human Papillomavirus Entry and Subcellular Trafficking. Curr. Opin. Virol. 2021, 50, 76-86. [CrossRef]

44. Woodham, A.W.; Raff, A.B.; Raff, L.M.; Silva, D.M.D.; Yan, L.; Skeate, J.G.; Wong, M.K.; Lin, Y.G.; Kast, W.M. Inhibition of Langerhans Cell Maturation by Human Papillomavirus Type 16: A Novel Role for the Annexin A2 Heterotetramer in Immune Suppression. J. Immunol. 2014, 192, 4748-4757. [CrossRef]

45. Mikuličić, S.; Florin, L. The Endocytic Trafficking Pathway of Oncogenic Papillomaviruses. Papillomavirus Res. 2019, 7, 135-137. [CrossRef] [PubMed]

46. Culp, T.D.; Budgeon, L.R.; Marinkovich, M.P.; Meneguzzi, G.; Christensen, N.D. Keratinocyte-Secreted Laminin 5 Can Function as a Transient Receptor for Human Papillomaviruses by Binding Virions and Transferring Them to Adjacent Cells. J. Virol. 2006, 80, 8940-8950. [CrossRef]

47. Richards, K.F.; Mukherjee, S.; Bienkowska-Haba, M.; Pang, J.; Sapp, M. Human Papillomavirus Species-Specific Interaction with the Basement Membrane-Resident Non-Heparan Sulfate Receptor. Viruses 2014, 6, 4856-4879. [CrossRef] [PubMed]

48. Evander, M.; Frazer, I.H.; Payne, E.; Qi, Y.M.; Hengst, K.; McMillan, N.A. Identification of the Alpha6 Integrin as a Candidate Receptor for Papillomaviruses. J. Virol. 1997, 71, 2449-2456. [CrossRef] [PubMed]

49. McMillan, N.; Payne, E.; Frazer, I.; Evander, M. Expression of the [Alpha] 6 Integrin Confers Papillomavirus Binding upon Receptor-Negative B-Cells. Virology 1999, 261, 271-279. [CrossRef] [PubMed]

50. Finke, J.; Mikuličić, S.; Loster, A.-L.; Gawlitza, A.; Florin, L.; Lang, T. Anatomy of a Viral Entry Platform Differentially Functionalized by Integrins A3 and A6. Sci. Rep. 2020, 10, 5356-17. [CrossRef]

51. Levy, S.; Shoham, T. Protein-Protein Interactions in the Tetraspanin Web. Physiology 2005, 20, 218-224. [CrossRef] [PubMed]

52. Charrin, S.; Naour, F.L.; Silvie, O.; Milhiet, P.-E.; Boucheix, C.; Rubinstein, E. Lateral Organization of Membrane Proteins: Tetraspanins Spin Their Web. Biol. J. 2009, 420, 133-154. [CrossRef] [PubMed]

53. Berditchevski, F.; Odintsova, E. ErbB Receptors and Tetraspanins: Casting the Net Wider. Int. J. Biochem. Cell Biol. 2016, 77, 68-71. [CrossRef]

54. Berditchevski, F.; Gilbert, E.; Griffiths, M.R.; Fitter, S.; Ashman, L.; Jenner, S.J. Analysis of the CD151-Alpha3beta1 Integrin and CD151-Tetraspanin Interactions by Mutagenesis. J. Biol. Chem. 2001, 276, 41165-41174. [CrossRef]

55. Stipp, C.S. Laminin-Binding Integrins and Their Tetraspanin Partners as Potential Antimetastatic Targets. Expert Rev. Mol. Med. 2010, 12, e3. [CrossRef] [PubMed]

56. Scheffer, K.D.; Gawlitza, A.; Spoden, G.A.; Zhang, X.A.; Lambert, C.; Berditchevski, F.; Florin, L. Tetraspanin CD151 Mediates Papillomavirus Type 16 Endocytosis. J. Virol. 2013, 87, 3435-3446. [CrossRef] [PubMed]

57. Spoden, G.; Kühling, L.; Cordes, N.; Frenzel, B.; Sapp, M.; Boller, K.; Florin, L.; Schelhaas, M. Human Papillomavirus Types 16, 18, and 31 Share Similar Endocytic Requirements for Entry. J. Virol. 2013, 87, 7765-7773. [CrossRef] 
58. Spoden, G.; Freitag, K.; Husmann, M.; Boller, K.; Sapp, M.; Lambert, C.; Florin, L. Clathrin- and Caveolin-Independent Entry of Human Papillomavirus Type 16-Involvement of Tetraspanin-Enriched Microdomains (TEMs). PLoS ONE 2008, 3 , e3313. [CrossRef] [PubMed]

59. Fast, L.A.; Mikuličić, S.; Fritzen, A.; Schwickert, J.; Boukhallouk, F.; Hochdorfer, D.; Sinzger, C.; Suárez, H.; Monk, P.N.; Yañez-Mó, M.; et al. Inhibition of Tetraspanin Functions Impairs Human Papillomavirus and Cytomegalovirus Infections. Int. J. Mol. Sci. 2018, 19, 3007. [CrossRef]

60. Florin, L.; Lang, T. Tetraspanin Assemblies in Virus Infection. Front. Immunol. 2018, 9, 1140. [CrossRef]

61. Fast, L.A.; Lieber, D.; Lang, T.; Florin, L. Tetraspanins in Infections by Human Cytomegalo- and Papillomaviruses. Biochem. Soc. Trans. 2017, 45, 489-497. [CrossRef]

62. Buck, C.B.; Day, P.M.; Thompson, C.D.; Lubkowski, J.; Lu, W.; Lowy, D.R.; Schiller, J.T. Human Alpha-Defensins Block Papillomavirus Infection. Proc. Natl. Acad. Sci. USA 2006, 103, 1516-1521. [CrossRef]

63. Wiens, M.E.; Smith, J.G. Alpha-Defensin HD5 Inhibits Furin Cleavage of Human Papillomavirus 16 L2 To Block Infection. J. Virol. 2015, 89, 2866-2874. [CrossRef] [PubMed]

64. Gulati, N.M.; Miyagi, M.; Wiens, M.E.; Smith, J.G.; Stewart, P. $\alpha$-Defensin HD5 Stabilizes Human Papillomavirus 16 Capsid/Core Interactions. Pathog. Immun. 2019, 4, 196-234. [CrossRef]

65. Wiens, M.E.; Smith, J.G. $\alpha$-Defensin HD5 Inhibits Human Papillomavirus 16 Infection via Capsid Stabilization and Redirection to the Lysosome. MBio 2017, 8, e02304-16. [CrossRef]

66. Schäfer, G.; Graham, L.M.; Lang, D.M.; Blumenthal, M.J.; Marušič, M.B.; Katz, A.A. Vimentin Modulates Infectious Internalization of Human Papillomavirus 16 Pseudovirions. J. Virol. 2017, 91, e00307-17. [CrossRef] [PubMed]

67. Day, P.M.; Thompson, C.D.; Lowy, D.R.; Schiller, J.T. Interferon Gamma Prevents Infectious Entry of Human Papillomavirus 16 via an L2-Dependent Mechanism. J. Virol. 2017, 91, e00168-17. [CrossRef] [PubMed]

68. Griffin, L.M.; Cicchini, L.; Pyeon, D. Human Papillomavirus Infection Is Inhibited by Host Autophagy in Primary Human Keratinocytes. Virology 2013, 437, 12-19. [CrossRef]

69. Broniarczyk, J.; Bergant, M.; Goździcka-Józefiak, A.; Banks, L. Human Papillomavirus Infection Requires the TSG101 Component of the ESCRT Machinery. Virology 2014, 460-461, 83-90. [CrossRef] [PubMed]

70. Calton, C.M.; Schlegel, A.M.; Chapman, J.A.; Campos, S.K. Human Papillomavirus Type 16 Does Not Require Cathepsin L or B for Infection. J. Gen. Virol. 2013, 94, 1865-1869. [CrossRef]

71. Uhlorn, B.L.; Jackson, R.; Li, S.; Bratton, S.M.; Doorslaer, K.V.; Campos, S.K. Vesicular Trafficking Permits Evasion of CGAS/STING Surveillance during Initial Human Papillomavirus Infection. PLoS Pathog. 2020, 16, e1009028. [CrossRef] [PubMed]

72. Stepp, W.H.; Meyers, J.M.; McBride, A.A. Sp100 Provides Intrinsic Immunity against Human Papillomavirus Infection. MBio 2013, 4, e00845-13. [CrossRef] [PubMed]

73. Guion, L.; Bienkowska-Haba, M.; DiGiuseppe, S.; Florin, L.; Sapp, M. PML Nuclear Body-Residing Proteins Sequentially Associate with HPV Genome after Infectious Nuclear Delivery. PLoS Pathog. 2019, 15, e1007590. [CrossRef]

74. Lipovsky, A.; Erden, A.; Kanaya, E.; Zhang, W.; Crite, M.; Bradfield, C.; MacMicking, J.; DiMaio, D.; Schoggins, J.W.; Iwasaki, A. The Cellular Endosomal Protein Stannin Inhibits Intracellular Trafficking of Human Papillomavirus during Virus Entry. J. Gen. Virol. 2017, 98, 2821-2836. [CrossRef]

75. Schneider, M.A.; Scheffer, K.D.; Bund, T.; Boukhallouk, F.; Lambert, C.; Cotarelo, C.; Pflugfelder, G.O.; Florin, L.; Spoden, G.A. The Transcription Factors TBX2 and TBX3 Interact with Human Papillomavirus 16 (HPV16) L2 and Repress the Long Control Region of HPVs. J. Virol. 2013, 87, 4461-4474. [CrossRef]

76. Bannach, C.; Brinkert, P.; Kühling, L.; Greune, L.; Schmidt, M.A.; Schelhaas, M. Epidermal Growth Factor Receptor and Abl2 Kinase Regulate Distinct Steps of Human Papillomavirus 16 Endocytosis. J. Virol. 2020, 94, 342. [CrossRef] [PubMed]

77. Gräßel, L.; Fast, L.A.; Scheffer, K.D.; Boukhallouk, F.; Spoden, G.A.; Tenzer, S.; Boller, K.; Bago, R.; Rajesh, S.; Overduin, M.; et al. The CD63-Syntenin-1 Complex Controls Post-Endocytic Trafficking of Oncogenic Human Papillomaviruses. Sci. Rep. 2016, 6, 32337. [CrossRef] [PubMed]

78. Bienkowska-Haba, M.; Sapp, M. The Cytoskeleton in Papillomavirus Infection. Viruses 2011, 3, 260-271. [CrossRef] [PubMed]

79. Balaji, K.; Mooser, C.; Janson, C.M.; Bliss, J.M.; Hojjat, H.; Colicelli, J. RIN1 Orchestrates the Activation of RAB5 GTPases and ABL Tyrosine Kinases to Determine the Fate of EGFR. J. Cell Sci. 2012, 125, 5887-5896. [CrossRef] [PubMed]

80. Wüstenhagen, E.; Hampe, L.; Boukhallouk, F.; Schneider, M.A.; Spoden, G.A.; Negwer, I.; Koynov, K.; Kast, W.M.; Florin, L. The Cytoskeletal Adaptor Obscurin-Like 1 Interacts with the Human Papillomavirus 16 (HPV16) Capsid Protein L2 and Is Required for HPV16 Endocytosis. J. Virol. 2016, 90, 10629-10641. [CrossRef]

81. Finke, J.; Hitschler, L.; Boller, K.; Florin, L.; Lang, T. HPV Caught in the Tetraspanin Web? Med. Microbio. Immunol. 2020, 209, 447-459. [CrossRef]

82. Brinkert, P.; Krebs, L.; Ventayol, P.S.; Greune, L.; Bannach, C.; Bucher, D.; Kollasser, J.; Dersch, P.; Boulant, S.; Stradal, T.E.B.; et al Endocytic Vacuole Formation by WASH-Mediated Endocytosis. bioRxiv 2021. [CrossRef]

83. Ishii, Y.; Nakahara, T.; Kataoka, M.; Kusumoto-Matsuo, R.; Mori, S.; Takeuchi, T.; Kukimoto, I. Identification of TRAPPC8 as a Host Factor Required for Human Papillomavirus Cell Entry. PLoS ONE 2013, 8, e80297. [CrossRef] [PubMed]

84. Taylor, J.R.; Fernandez, D.J.; Thornton, S.M.; Skeate, J.G.; Lühen, K.P.; Silva, D.M.D.; Langen, R.; Kast, W.M. Heterotetrameric Annexin A2/S100A10 (A2t) Is Essential for Oncogenic Human Papillomavirus Trafficking and Capsid Disassembly, and Protects Virions from Lysosomal Degradation. Sci. Rep. 2018, 8, 11642. [CrossRef] 
85. Broniarczyk, J.; Pim, D.; Massimi, P.; Bergant, M.; Goździcka-Józefiak, A.; Crump, C.; Banks, L. The VPS4 Component of the ESCRT Machinery Plays an Essential Role in HPV Infectious Entry and Capsid Disassembly. Sci. Rep. 2017, 7, 45159. [CrossRef]

86. Bergant, M.; Peternel, Š.; Pim, D.; Broniarczyk, J.; Banks, L. Characterizing the Spatio-Temporal Role of Sorting Nexin 17 in Human Papillomavirus Trafficking. J. Gen. Virol. 2017, 98, 715-725. [CrossRef] [PubMed]

87. Valdano, M.B.; Massimi, P.; Broniarczyk, J.; Pim, D.; Myers, M.; Gardiol, D.; Banks, L. Human Papillomavirus Infection Requires the CCT Chaperonin Complex. J. Virol. 2021, 95, e01943-2. [CrossRef]

88. Marušič, M.B.; Ozbun, M.A.; Campos, S.K.; Myers, M.P.; Banks, L. Human Papillomavirus L2 Facilitates Viral Escape from Late Endosomes via Sorting Nexin 17. Traffic 2012, 13, 455-467. [CrossRef]

89. Tomoda, T.; Kim, J.H.; Zhan, C.; Hatten, M.E. Role of Unc51.1 and Its Binding Partners in CNS Axon Outgrowth. Genes Dev. 2004, 18, 541-558. [CrossRef]

90. Young, J.M.; Abidine, A.Z.E.; Gómez-Martinez, R.A.; Ozbun, M.A. The Known and Potential Intersections of Rab-GTPases in Human Papillomavirus Infections. Front. Cell Dev. Biol. 2019, 7, 139. [CrossRef]

91. Bharadwaj, A.; Bydoun, M.; Holloway, R.; Waisman, D. Annexin A2 Heterotetramer: Structure and Function. Int. J. Mol. Sci. 2013, 14, 6259-6305. [CrossRef]

92. Lipovsky, A.; Popa, A.; Pimienta, G.; Wyler, M.; Bhan, A.; Kuruvilla, L.; Guie, M.-A.; Poffenberger, A.C.; Nelson, C.D.S.; Atwood, W.J.; et al. Genome-Wide SiRNA Screen Identifies the Retromer as a Cellular Entry Factor for Human Papillomavirus. Proc. Natl. Acad. Sci. USA 2013, 110, 7452-7457. [CrossRef]

93. Müller, K.H.; Spoden, G.A.; Scheffer, K.D.; Brunnhöfer, R.; Brabander, J.K.D.; Maier, M.E.; Florin, L.; Muller, C.P. Inhibition by cellular vacuolar ATPase impairs human papillomavirus uncoating and infection. Antimicrob. Agents Chemother. 2014, 58, 2905-2911. [CrossRef]

94. Bienkowska-Haba, M.; Williams, C.; Kim, S.M.; Garcea, R.L.; Sapp, M. Cyclophilins Facilitate Dissociation of the HPV16 Capsid Protein L1 from the L2/DNA Complex Following Virus Entry. J. Virol. 2012, 86, 9875-9887. [CrossRef] [PubMed]

95. DiGiuseppe, S.; Keiffer, T.R.; Bienkowska-Haba, M.; Luszczek, W.; Guion, L.G.M.; Müller, M.; Sapp, M. Topography of the Human Papillomavirus Minor Capsid Protein L2 during Vesicular Trafficking of Infectious Entry. J. Virol. 2015, 89, 10442-10452. [CrossRef]

96. Kuo, C.-J.; Hansen, M.; Troemel, E. Autophagy and Innate Immunity: Insights from Invertebrate Model Organisms. Autophagy 2017, 14, 233-242. [CrossRef]

97. Ishii, Y. Electron Microscopic Visualization of Autophagosomes Induced by Infection of Human Papillomavirus Pseudovirions. Biochem. Biophys. Res. Commun. 2013, 433, 385-389. [CrossRef] [PubMed]

98. Besemer, A.S.; Maus, J.; Ax, M.D.A.; Stein, A.; Vo, S.; Freese, C.; Nalbach, K.; von Hilchen, C.; Pfalzgraf, I.F.; Koziollek-Drechsler, I.; et al. Receptor-Mediated Endocytosis 8 (RME-8)/DNAJC13 Is a Novel Positive Modulator of Autophagy and Stabilizes Cellular Protein Homeostasis. Cell. Mol. Life Sci. 2020, 21, 1406-1416. [CrossRef]

99. Xie, J.; Zhang, P.; Crite, M.; DiMaio, D. Papillomaviruses Go Retro. Pathogens 2020, 9, 267. [CrossRef]

100. Kämper, N.; Day, P.M.; Nowak, T.; Selinka, H.-C.; Florin, L.; Bolscher, J.; Hilbig, L.; Schiller, J.T.; Sapp, M. A MembraneDestabilizing Peptide in Capsid Protein L2 Is Required for Egress of Papillomavirus Genomes from Endosomes. J. Virol. 2006, 80, 759-768. [CrossRef] [PubMed]

101. Zhang, P.; da Silva, G.M.; Deatherage, C.; Burd, C.; Dimaio, D. Cell-Penetrating Peptide Mediates Intracellular Membrane Passage of Human Papillomavirus L2 Protein to Trigger Retrograde Trafficking. Cell 2018, 174, 1465-1476. [CrossRef]

102. Bronnimann, M.P.; Chapman, J.A.; Park, C.K.; Campos, S.K. A Transmembrane Domain and GxxxG Motifs within L2 Are Essential for Papillomavirus Infection. J. Virol. 2013, 87, 464-473. [CrossRef] [PubMed]

103. Harwood, M.C.; Dupzyk, A.J.; Inoue, T.; Dimaio, D.; Tsai, B. P120 Catenin Recruits HPV to $\gamma$-Secretase to Promote Virus Infection. PLoS Pathog. 2020, 16, e1008946. [CrossRef]

104. Inoue, T.; Zhang, P.; Zhang, W.; Goodner-Bingham, K.; Dupzyk, A.; DiMaio, D.; Tsai, B. $\gamma$-Secretase Promotes Membrane Insertion of the Human Papillomavirus L2 Capsid Protein during Virus Infection. J. Cell Biol. 2018, 217, 3545-3559. [CrossRef] [PubMed]

105. Zhang, W.; Kazakov, T.; Popa, A.; Dimaio, D. Vesicular Trafficking of Incoming Human Papillomavirus 16 to the Golgi Apparatus and Endoplasmic Reticulum Requires $\gamma$-Secretase Activity. MBio 2014, 5, e01777-14. [CrossRef] [PubMed]

106. Karanam, B.; Peng, S.; Li, T.; Buck, C.; Day, P.M.; Roden, R.B.S. Papillomavirus Infection Requires $\gamma$ Secretase. J. Virol. 2010, 84, 10661-10670. [CrossRef]

107. Campos, S.K.; Chapman, J.A.; Deymier, M.J.; Bronnimann, M.P.; Ozbun, M.A. Opposing Effects of Bacitracin on Human Papillomavirus Type 16 Infection: Enhancement of Binding and Entry and Inhibition of Endosomal Penetration. J. Virol. 2012, 86, 4169-4181. [CrossRef]

108. Huang, H.-S.; Buck, C.B.; Lambert, P.F. Inhibition of Gamma Secretase Blocks HPV Infection. Virology 2010, 407, 391-396. [CrossRef]

109. Florin, L.; Becker, K.A.; Sapp, C.; Lambert, C.; Sirma, H.; Müller, M.; Streeck, R.E.; Sapp, M. Nuclear Translocation of Papillomavirus Minor Capsid Protein L2 Requires Hsc70. J. Virol. 2004, 78, 5546-5553. [CrossRef]

110. Wakabayashi, T.; Craessaerts, K.; Bammens, L.; Bentahir, M.; Borgions, F.; Herdewijn, P.; Staes, A.; Timmerman, E.; Vandekerckhove, J.; Rubinstein, E.; et al. Analysis of the Gamma-Secretase Interactome and Validation of Its Association with Tetraspanin-Enriched Microdomains. Nature 2009, 11, 1340-1346. [CrossRef] 
111. DiGiuseppe, S.; Luszczek, W.; Keiffer, T.R.; Bienkowska-Haba, M.; Guion, L.G.M.; Sapp, M.J. Incoming Human Papillomavirus Type 16 Genome Resides in a Vesicular Compartment throughout Mitosis. Proc. Natl. Acad. Sci. USA 2016, 113, 6289-6294. [CrossRef]

112. DiGiuseppe, S.; Bienkowska-Haba, M.; Guion, L.G.M.; Keiffer, T.R.; Sapp, M. Human Papillomavirus Major Capsid Protein L1 Remains Associated with the Incoming Viral Genome throughout the Entry Process. J. Virol. 2017, 91, e00537-17. [CrossRef] [PubMed]

113. Day, P.M.; Weisberg, A.S.; Thompson, C.D.; Hughes, M.M.; Pang, Y.Y.; Lowy, D.R.; Schiller, J.T. Human Papillomavirus 16 Capsids Mediate Nuclear Entry during Infection. J. Virol. 2019, 93, e00454-19. [CrossRef] [PubMed]

114. Popa, A.; Zhang, W.; Harrison, M.S.; Goodner, K.; Kazakov, T.; Goodwin, E.C.; Lipovsky, A.; Burd, C.G.; Dimaio, D. Direct Binding of Retromer to Human Papillomavirus Type 16 Minor Capsid Protein L2 Mediates Endosome Exit during Viral Infection. PLoS Pathog. 2015, 11, e1004699. [CrossRef]

115. Pim, D.; Broniarczyk, J.; Siddiqa, A.; Massimi, P.; Banks, L. Human Papillomavirus 16 L2 Recruits Both Retromer and Retriever Complexes during Retrograde Trafficking of the Viral Genome to the Cell Nucleus. J. Virol. 2021, 95, e02068-20. [CrossRef] [PubMed]

116. Siddiqa, A.; Massimi, P.; Pim, D.; Broniarczyk, J.; Banks, L. Human Papillomavirus 16 Infection Induces VAP-Dependent Endosomal Tubulation. J. Virol. 2018, 92, e01514-17. [CrossRef] [PubMed]

117. Xie, J.; Heim, E.N.; Crite, M.; DiMaio, D. TBC1D5-Catalyzed Cycling of Rab7 Is Required for Retromer-Mediated Human Papillomavirus Trafficking during Virus Entry. Cell Rep. 2020, 31, 107750. [CrossRef]

118. Day, P.M.; Thompson, C.D.; Schowalter, R.M.; Lowy, D.R.; Schiller, J.T. Identification of a Role for the Trans-Golgi Network in Human Papillomavirus 16 Pseudovirus Infection. J. Virol. 2013, 87, 3862-3870. [CrossRef] [PubMed]

119. Pyeon, D.; Pearce, S.M.; Lank, S.M.; Ahlquist, P.; Lambert, P.F. Establishment of Human Papillomavirus Infection Requires Cell Cycle Progression. PLoS Pathog. 2009, 5, e1000318. [CrossRef]

120. Calton, C.M.; Bronnimann, M.P.; Manson, A.R.; Li, S.; Chapman, J.A.; Suarez-Berumen, M.; Williamson, T.R.; Molugu, S.K.; Bernal, R.A.; Campos, S.K. Translocation of the Papillomavirus L2/VDNA Complex across the Limiting Membrane Requires the Onset of Mitosis. PLoS Pathog. 2017, 13, e1006200. [CrossRef]

121. Gottschalk, E.Y.; Meneses, P.I. A Dual Role for the Nonreceptor Tyrosine Kinase Pyk2 during the Intracellular Trafficking of Human Papillomavirus 16. J. Virol. 2015, 89, 9103-9114. [CrossRef] [PubMed]

122. Litterman, N.; Ikeuchi, Y.; Gallardo, G.; O’Connell, B.C.; Sowa, M.E.; Gygi, S.P.; Harper, J.W.; Bonni, A. An OBSL1-Cul7 Fbxw8 Ubiquitin Ligase Signaling Mechanism Regulates Golgi Morphology and Dendrite Patterning. PLoS Biol. 2011, 9, e1001060. [CrossRef] [PubMed]

123. Florin, L.; Becker, K.A.; Lambert, C.; Nowak, T.; Sapp, C.; Strand, D.; Streeck, R.E.; Sapp, M. Identification of a Dynein Interacting Domain in the Papillomavirus Minor Capsid Protein L2. J. Virol. 2006, 80, 6691-6696. [CrossRef] [PubMed]

124. Schneider, M.A.; Spoden, G.A.; Florin, L.; Lambert, C. Identification of the Dynein Light Chains Required for Human Papillomavirus Infection. Cell. Microbiol. 2011, 13, 32-46. [CrossRef]

125. Aydin, I.; Weber, S.; Snijder, B.; Ventayol, P.S.; Kühbacher, A.; Becker, M.; Day, P.M.; Schiller, J.T.; Kann, M.; Pelkmans, L.; et al. Large Scale RNAi Reveals the Requirement of Nuclear Envelope Breakdown for Nuclear Import of Human Papillomaviruses. PLoS Pathog. 2014, 10, e1004162. [CrossRef]

126. Aydin, I.; Villalonga-Planells, R.; Greune, L.; Bronnimann, M.P.; Calton, C.M.; Becker, M.; Lai, K.-Y.; Campos, S.K.; Schmidt, M.A.; Schelhaas, M. A Central Region in the Minor Capsid Protein of Papillomaviruses Facilitates Viral Genome Tethering and Membrane Penetration for Mitotic Nuclear Entry. PLoS Pathog. 2017, 13, e1006308. [CrossRef] [PubMed]

127. Lai, K.-Y.; Rizzato, M.; Aydin, I.; Villalonga-Planells, R.; Drexler, H.C.A.; Schelhaas, M. A Ran-Binding Protein Facilitates Nuclear Import of Human Papillomavirus Type 16. PLoS Pathog. 2021, 17, e1009580. [CrossRef]

128. Darshan, M.S.; Lucchi, J.; Harding, E.; Moroianu, J. The L2 Minor Capsid Protein of Human Papillomavirus Type 16 Interacts with a Network of Nuclear Import Receptors. J. Virol. 2004, 78, 12179-12188. [CrossRef] [PubMed]

129. Mamoor, S.; Onder, Z.; Karanam, B.; Kwak, K.; Bordeaux, J.; Crosby, L.; Roden, R.B.S.; Moroianu, J. The High Risk HPV16 L2 Minor Capsid Protein Has Multiple Transport Signals That Mediate Its Nucleocytoplasmic Traffic. Virology 2012, 422, 413-424. [CrossRef] [PubMed]

130. Becker, K.A.; Florin, L.; Sapp, C.; Sapp, M. Dissection of Human Papillomavirus Type 33 L2 Domains Involved in Nuclear Domains (ND) 10 Homing and Reorganization. Virology 2003, 314, 161-167. [CrossRef]

131. Bund, T.; Spoden, G.A.; Koynov, K.; Hellmann, N.; Boukhallouk, F.; Arnold, P.; Hinderberger, D.; Florin, L. A L2 SUMO Interacting Motif Is Important for PML-Localization and Infection of Human Papillomavirus Type 16. Cell. Microbiol. 2014, 16, 1179-1200. [CrossRef]

132. Marusic, M.B.; Mencin, N.; Licen, M.; Banks, L.; Grm, H.S. Modification of Human Papillomavirus Minor Capsid Protein L2 by Sumoylation. J. Virol. 2010, 84, 11585-11589. [CrossRef]

133. Florin, L.; Schäfer, F.; Sotlar, K.; Streeck, R.E.; Sapp, M. Reorganization of Nuclear Domain 10 Induced by Papillomavirus Capsid Protein L2. Virology 2002, 295, 97-107. [CrossRef] [PubMed]

134. Day, P.M.; Baker, C.C.; Lowy, D.R.; Schiller, J.T. Establishment of Papillomavirus Infection Is Enhanced by Promyelocytic Leukemia Protein (PML) Expression. Proc. Natl. Acad. Sci. USA 2004, 101, 14252-14257. [CrossRef] [PubMed] 
135. Bienkowska-Haba, M.; Luszczek, W.; Keiffer, T.R.; Guion, L.G.M.; DiGiuseppe, S.; Scott, R.S.; Sapp, M. Incoming Human Papillomavirus 16 Genome Is Lost in PML Protein-Deficient HaCaT Keratinocytes. Cell. Microbiol. 2017, 19, e12708. [CrossRef]

136. Hantak, M.P.; Qing, E.; Earnest, J.T.; Gallagher, T. Tetraspanins: Architects of Viral Entry and Exit Platforms. J. Virol. 2019, 93, 674. [CrossRef] [PubMed]

137. Moody, C.A.; Laimins, L.A. Human Papillomavirus Oncoproteins: Pathways to Transformation. Nat. Rev. Cancer 2010, 10, 550-560. [CrossRef] [PubMed]

138. Münger, K.; Scheffner, M.; Huibregtse, J.M.; Howley, P.M. Interactions of HPV E6 and E7 Oncoproteins with Tumour Suppressor Gene Products. Cancer Surv. 1992, 12, 197-217. [PubMed]

139. Yang, R.; Yutzy, W.H.; Viscidi, R.P.; Roden, R.B.S. Interaction of L2 with $\beta$-Actin Directs Intracellular Transport of Papillomavirus and Infection. J. Biol. Chem. 2003, 278, 12546-12553. [CrossRef] [PubMed]

140. Cruz, L.; Biryukov, J.; Conway, M.J.; Meyers, C. Cleavage of the HPV16 Minor Capsid Protein L2 during Virion Morphogenesis Ablates the Requirement for Cellular Furin during De Novo Infection. Viruses 2015, 7, 5813-5830. [CrossRef]

141. Zhang, P.; Moreno, R.; Lambert, P.F.; DiMaio, D. Cell-Penetrating Peptide Inhibits Retromer-Mediated Human Papillomavirus Trafficking during Virus Entry. Proc. Nat. Acad. Sci. USA 2020, 117, 6121-6128. [CrossRef] [PubMed]

142. Pim, D.; Broniarczyk, J.; Bergant, M.; Playford, M.P.; Banks, L. A Novel PDZ Domain Interaction Mediates the Binding between Human Papillomavirus 16 L2 and Sorting Nexin 27 and Modulates Virion Trafficking. J. Virol. 2015, 89, 10145-10155. [CrossRef] [PubMed]

143. Görnemann, J.; Hofmann, T.G.; Will, H.; Müller, M. Interaction of Human Papillomavirus Type 16 L2 with Cellular Proteins: Identification of Novel Nuclear Body-Associated Proteins. Virology 2002, 303, 69-78. [CrossRef] [PubMed] 